\title{
KAJIAN ORNAMEN PADA RUMAH TRADISIONAL MADURA
}

\author{
Dyan Agustin ${ }^{1,{ }^{*}}$, Nur Rahmatul Lailiyah ${ }^{2}$, Mu'ammar Fadhil $^{3}$, M.Ferdiyan Arya ${ }^{4}$ \\ ${ }^{1,2,3,4}$ Program Studi Arsitektur, Fakultas Arsitektur dan Desain, UPN Veteran Jatim, \\ Rungkut Madya Gunung Anyar Surabaya,60294 \\ *dyanagustin.ar@upnjatim.ac.id
}

Diterima: 15-04-2020Ｄireview : 19-04-2020Ｄirevisi: 15-05-2020Ｄisetujui: 17-05-2020

\begin{abstract}
ABSTRAK. Ornamen merupakan suatu hiasan yang dibentuk dengan mengembangkan dari bentukbentuk yang ada di alam. Ornamen pada bangunan tradisional berbentuk ragam hias dimana teknik maupun pengungkapannya dibuat menurut aturan-aturan, norma serta pola yang telah digariskan dan menjadi kesepakatan bersama dan diwariskan secara turun temurun. Pada rumah tinggal Madura, terdapat ornamen dalam elemen arsitekturalnya dimana keberadaan ornamen tersebut tidak lepas dari adanya akulturasi kebudayaan antar suku yang menetap di Madura. Penelitian ini membahas akulturasi kebudayaan mana saja yang mempengaruhi bentuk, warna ornamen di rumah tradisional Madura serta makna dari masing-masing motif ornamen yang digunakan. Metode yang digunakan adalah metode kualitatif dengan analisis deduktif untuk mengetahui rupa visual dari ornamen pada rumah tradisional di Madura. Hasil analisis menunjukkan beberapa motif yang digunakan pada rumah tradisional Madura antara lain motif flora, fauna antara lain motif ekor ular, naga, burung phoenix dan motif swastika. Pada motif flora-swastika merupakan akulturasi kebudayaan dari Cina, Jawa hindu, dan Madura. Motif flora fauna didominasi dengan hasil akulturasi budaya antara Madura dengan Cina. Untuk area penempatan ornamen bagian atap, dinding, pintu, kolom. Sedangkan penempatan ormanen pada komplek hunian Tanean Lanjhang adalah roma tongghuh (rumah induk) dan Roma na'poto (Rumah Anak). Sedangkan pada kobhung (langgar), tanean (halaman), dapor (dapur), kandhang (kandang) tidak terdapat ornamen karena tempat tersebut lebih diutamakan segi fungsinya.
\end{abstract}

Kata kunci: Ornamen, Rumah, Madura

ABSTRACT. Ornament is a decoration that is formed by developing from the forms that exist in nature. Ornaments in traditional buildings are in the form of decoration. The techniques and disclosures are made according to the rules, norms, and patterns that have been outlined and become collective agreements and passed down from generation to generation. In Madura's house, there is an ornament in its architectural element where the decoration's existence is inseparable from the acculturation of cultures between tribes who settled in Madura. This study discusses which cultural acculturation influences the shape, the colour of ornaments in traditional Madurese homes, and the meaning of each ornamental motif used. The method used is a qualitative method with a deductive research method to determine the visual appearance of ornaments in traditional houses in Madura. The analysis results showed several motifs used in traditional Madurese homes, including flora and fauna motifs, including snake-tailed motifs, dragons, phoenixes, and swastika motifs. The floraswastika motif is an acculturation of culture from China, Hinduism, Java, and Madura. The motif of flora and fauna is dominated by the results of cultural acculturation between Madura and China. For the ornamental placement area of the roof, walls, doors, columns. The placement of people in Tanean Lanjhang residential complex is Rome Tongghuh (main house) and Roma na'poto (Children's House). While in kobhung (langgar), tanean (page), dapor (kitchen), kandhang (cage), there are no ornaments because the place is preferred in terms of function.

Keywords: Ornament, House, Madura

\section{PENDAHULUAN}

Indonesia merupakan negara yang kaya akan keanekaragamannya, baik suku, bangsa, bahasa, agama, ras, dan budaya. Keanekaragaman tersebut memiliki ciri khasnya masing-masing. Salah satu dari keanekaragaman tersebut adalah suku Madura. Madura banyak menyimpan kebudayaan tersendiri seperti kebudayaan ide, tindakan maupun artefak yang ada. Pulau yang terkenal dengan persebaran agama 
Islam ini mempunyaibanyak keunikan tersendiri (Faried, 2015).

Akan tetapi, penduduk yang menduduki Pulau Madura tidak hanya berasal dari suku Madura, melainkan ada beberapa daerah yang penduduknya merupakan campuran keuturunan antara suku Jawa dan Madura, suku Bali dan Madura, suku Bugis-MakasarMadura, bangsa Arab dan Madura, serta terdapat campuran dengan suku bangsa Cina. Pencampuran keturunan tersebut memiliki keterkaitan dengan sejarah Madura khususnya Sumenep dengan imigran Cina, Kolonial Belanda, Kolonial Inggris, Kerajaan JawaIslam, serta Kerajaan Jawa Hindu/Buddha. Dengan kata lain, Madura menjadikan kebudayaan Jawa sebagai dasar bagi kebudayaan Madura sendiri (leluhur).

Salah satu warisan kebudayaan yang masih ada dan patut dilestarikan adalah rumah adat/rumah tinggal tradisional. Setiap daerah memiliki ciri khas masing-masing pada rumah adat/rumah tinggal tradisionalnya. Ciri khas tersebut dapat terlihat pada setiap elemenelemen arsitektural yang terdapat didalamnya. Pada rumah tinggal Madura, terdapat ornamen-ornamen dalam elemen arsitekturalnya. Keberadaan ornamen tersebut tidak lepas dari adanya akulturasi kebudayaan antar suku yang menetap di Madura. Keberadaan ornamen di Madura hanya terdapat pada bangunan keraton, bangsawan, dan beberapa rumah tinggal saja .

Ornamen berasal dari bahasa latin yaitu Ornare yang berarti hias, hiasan, atau menghiasi. Sedangkan menurut Gustami (1980), ornamen merupakan suatu komponen produk seni yang ditambahkan atau sengaja dibuat dengan tujuan sebagai hiasan. Jadi dapat dikatakan bahwa ornamen merupakan salah satu bentuk karya seni rupa yang banyak terdapat di lingkungan masyarakat dengan fungsi utama sebagai hiasan yang bersifat indah. Keberadaan ornamen bukanlah semata-mata untuk mengisi bagian yang kosong saja, akan tetapi memiliki beberapa fungsi tertentu, yakni sebagai fungsi murni estetis, fungsi simbolis, dan fungsi teknis konstruksi (Sunaryo, 2009). Seperti pada umumnya, mayoritas masyarakat mengetahui bahwa penggunaan ornamen pada suatu objek ditujukan sebagai pemberi keindahan saja. Akan tetapi pada beberapa daerah yang memiliki adat istiadat yang masih kental, ornamen lebih ditujukan sebagai suatu simbolsimbol tertentu atau dengan kata lain, ornamen disebutkan sebagai ungkapan perasaan yang diwujudkan dalam suatu karya seni rupa.

Ornamen pada rumah tinggal tradisional Madura banyak dipengaruhi oleh arsitektur Cina yang datang ke Sumenep. Hal ini tampak pada hiasan kanopi, ukiran dan detail lainnya dengan karakter bunga dan bentukan sulur (Wiryoprawiro, 1986).

\section{METODE PENELITIAN}

Penelitian ini menggunakan metode kualitatif dengan metoda penelitian deduktif untuk mengetahui rupa visual dari ornamen pada rumah tradisional di Madura dengan melihat sifat data penelitian. Data yang dikumpulkan berupa kata dalam kalimat atau gambar yang mempunyai arti lebih dari sekedar angka (Sutopo, 2002). Teknik pengumpulan data menggunakan alat alat penelitian antara lain observasi, studi pustaka dan dokumen (arsip). Observasi dilakukan dengan mengamati dan mencari data dan fakta tentang ornamen rumah tradisional Madura. Studi pustaka dilakukan untuk mendapatkan informasi dan referensi dari sumber pustaka yang berkaitan dengan penelitian. Kajian teoritis didapatkan dari buku, majalah, artikel dan laporan penelitian terkait dengan kajian penelitian.

\section{HASIL DAN PEMBAHASAN}

\section{Ragam Ornamen}

Arsitektur tradisional erat kaitannya dengan beberapa faktor, yakni alam dan iklim, material dan teknologi konstruksi, ekonomi, serta agama dan sosial budaya. Terjadinya akulturasi suku bangsa yang ada di Madura memberikan dampak pada komponen arsitektural yang ada. Dengan adanya akulturasi itu, rumah tinggal Madura memiliki suatu keunikan, yaitu adanya pencampuran dari berbagai budaya antara Madura, Cina, Belanda, Jawa, Islam. Hal tersebut terlihat pada beberapa elemen-elemen arsitektural yang ada pada rumah tinggal Madura, seperti pada bagian atap, kolom, kusen, serta dinding. Terdapat beberapa jenis ornamen yang ada pada rumah tinggal Madura, diantaranya:

\section{Motif Flora}

Motif flora/organik biasanya diletakkan pada dinding gejug dan diatas pintu guna sebagai ventilasi udara karena pada dasarnya konsep rumah tinggal Madura utamanya pemukiman Tanean Lanjhang menggunakan konsep ruang tertutup. Motif ukiran ini juga dilengkapi dengan warna khas Madura yaitu 
hijau, kuning dan merah atau gabungan warna antara ketiganya. Warna-warna tersebut merupakan simbolik dari kekuatan dan kejujuran. Motif ukiran ini yang kerap kali digunakan oleh masyarakat Madura pada umumnya. Motif flora tersebut adalah:

\section{- Okel (tumbuhan sulur)}

Motif ini dapat dikatakan sebagai perkembangan dari motif Jepara karena bentuknya yang terkesan hampir sama. Yang membedakan keduanya adalah bentuk sulur daun muda yang melengkung dengan ujung daun bergelung/mengikal (okel). Selain itu, pahatan yang berupa garis-garis pada ukiran daun merupakan hal lain yang membedakan antara motif Madura dengan Jepara. Biasanya motif ini disandingkan dengan motif bungabunga (Wiryoprawiro, 1986).

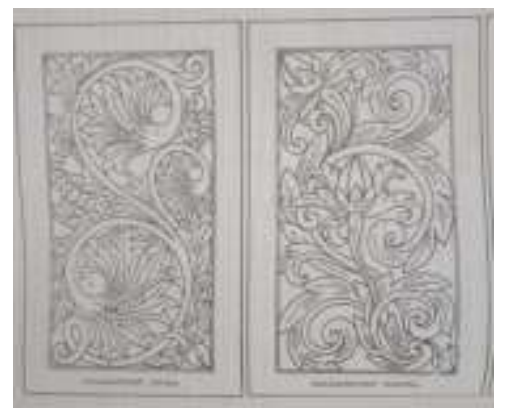

Gambar 1: motif ukiran Jepara (kiri), motif ukiran Madura (kanan)

(Sumber: Wiryoprawiro, 1986)

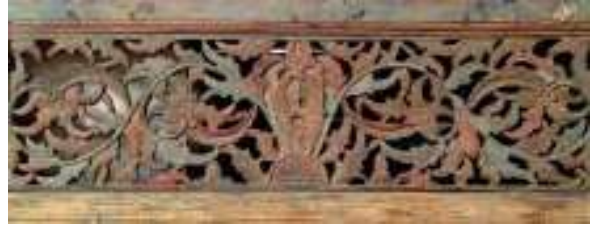

Gambar 2: motif ukiran tumbuhan sulur Sumber:pinterest

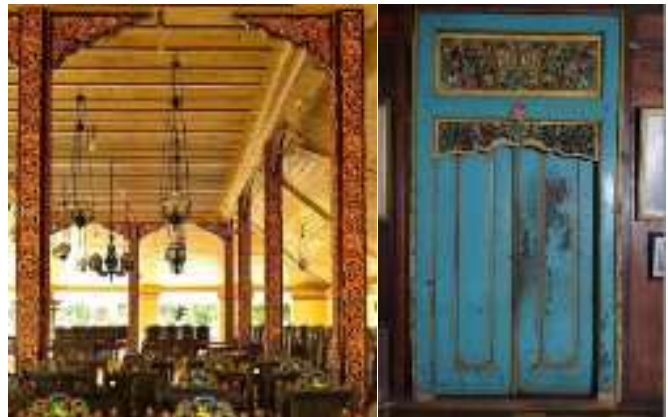

Gambar 3: ukiran daun sulur dan bunga pada kusen pintu(kiri) dan kolom (kanan)

Sumber: pinterest

Gambar-gambar tersebut menunjukkan bahwa motif okel/daun sulur yang disertai dengan bunga-bunga memang sangat disukai diantara motif lainnya karena itulah ciri khas yang dimiliki oleh Madura.

\section{Motif Fauna}

Motif fauna didominasi dengan hasil akulturasi budaya antara Madura dengan Cina tidak begitu banyak digunakan, biasanya terdapat pada bubungan atap serta pada kusen pintu ataupun jendela. Motif fauna yang ada antara lain:

\section{- $\quad$ Ekor ular/tanduk}

Terdapat pada hiasan bubungan yang saling berhadapan dan digunakan sebagai keindahan saja. Akan tetapi pada sekelompok keluarga yang religius, adanya motif ini pada atap rumah memumculkan sebuah simbolik yaitu sebagai gambaran batu nisan sehingga selalu mengingat kematian.

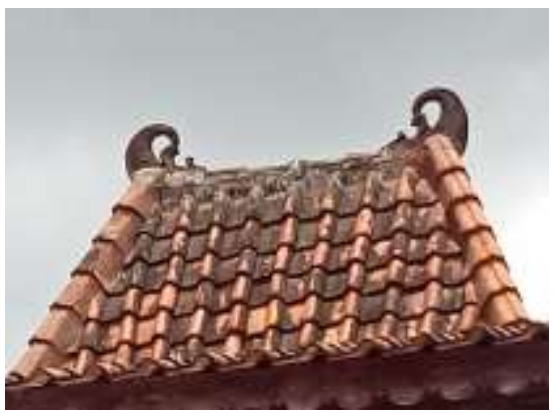

Gambar 4: rumah adat Bangsal Sumber:penulis

\section{- Naga/kondhe-kondhe}

Penggunaan ukiran dengan motif naga ini berada pada bagian atap. Ornamen bentuk ekor naga pada bubungan atap merupakan penanda status sosial pemilik rumah (Asmarani, 2016). Naga merupakan hasil akulturasi dengan budaya Cina yang mana memiliki makna keperkasaan dan dianggap sebagai penjaga rizki.

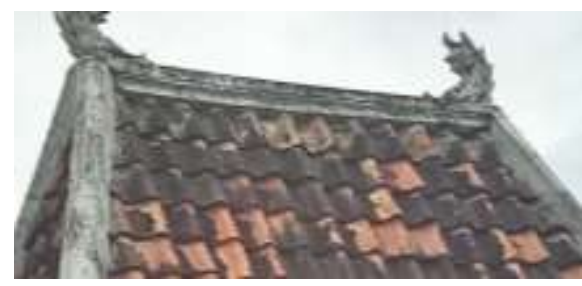

Gambar 5: atap rumah suku bangsal Sumber:penulis 


\section{- $\quad$ Burung phoenix}

Motif ini juga merupakan hasil akulturasi dengan budaya Cina yang biasanya bersandig dengan okel pada elemen dinding, pintu, dan kusen. Motif ini bagi masyarakat pendatang Cina menganggap bahwa ini sebagai simbol kebaktian dan kejujuran hati.

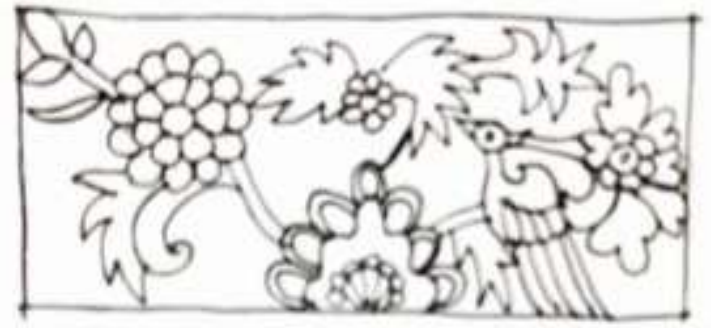

Gambar 6: ukiran pada kusen jendela Sumber: sketsa penulis

Pada gambar 6 diatas terdapat ukiran seekor burung ditengah-tengah ukiran tumbuhan sulur dengan warna yang cerah yakni hijau, kuning, merah dengan hijau yang mendominasi.

\section{Motif Swastika}

Motif swastika merupakan motif budaya Jawa hindu yang diadopsi oleh Madura. Akan tetapi penggunaan motif ini tidaklah begitu kentara karena lebih sering digunakan sebagai tepian ukiran motif okel. Motif swastika atau yang sering disebut sebagai motif geometris memiliki bentuk garis yang tegas dan cenderung berulang

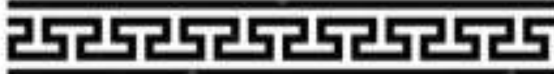

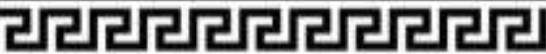

\section{चचचचचचा}

Gambar 7: macam motif swastika Sumber: dreamstime.com

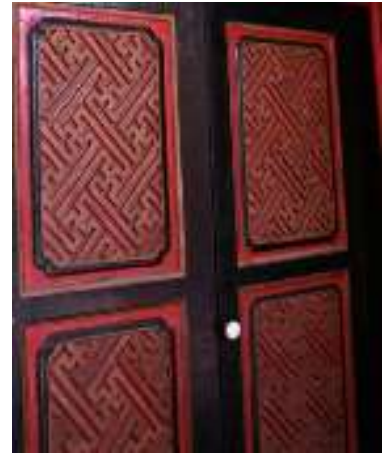

Gambar 8: motif geometris pada daun pintu di keraton Sumenep

Sumber: pinterest

\section{Motif gabungan}

Motif gabungan terdiri dari motif-motif yang ada yakni motif flora dengan swastika maupun flora dengan fauna. Pada motif flora-swastika merupakan akulturasi kebudayaan dari Cina, Jawa hindu, dan Madura. Sedangkan motif flora-fauna merupakan motif hasil akulturasi Madura dan Cina.

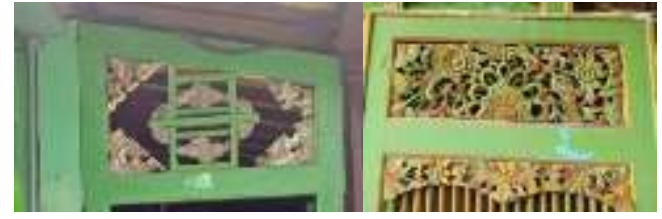

Gambar 9: motif flora-swastika (kiri), motif florafauna (kanan)

Sumber:kiri (penulis)

Tabel 1. Analisis Perbandingan Ornamen pada Rumah Rakyat dan Keraton

\begin{tabular}{|c|c|c|}
\hline Pembanding & Rumah Rakyat & $\begin{array}{l}\text { Keraton/Rumah } \\
\text { Bangsawan }\end{array}$ \\
\hline $\begin{array}{l}\text { Ornamen } \\
\text { atap }\end{array}$ & $\begin{array}{l}\text { Dapat berupa } \\
\text { ornamen } \\
\text { tanduk/ekor } \\
\text { ular/naga pada } \\
\text { bubungan atap }\end{array}$ & $\begin{array}{l}\text { Dapat berupa } \\
\text { ornamen } \\
\text { tanduk/ekor } \\
\text { ular/naga pada } \\
\text { bubungan atap }\end{array}$ \\
\hline $\begin{array}{l}\text { Ornamen } \\
\text { dinding }\end{array}$ & $\begin{array}{l}\text { Ornamen yang } \\
\text { sering } \\
\text { digunakan } \\
\text { adalah ornamen } \\
\text { flora/organik, } \\
\text { berupa okel }\end{array}$ & $\begin{array}{l}\text { Telah } \\
\text { menggunakan } \\
\text { ornamen hasil } \\
\text { akulturasi } \\
\text { walaupun } \\
\text { ornamen asli } \\
\text { masih terdapat di } \\
\text { beberapa bagian. }\end{array}$ \\
\hline $\begin{array}{l}\text { Ornamen } \\
\text { kusen }\end{array}$ & $\begin{array}{l}\text { Ornamen yang } \\
\text { sering } \\
\text { digunakan } \\
\text { adalah } \\
\text { ornamen } \\
\text { flora/organik, } \\
\text { berupa okel } \\
\text { terdapat } \\
\text { beberapa }\end{array}$ & $\begin{array}{l}\text { Telah } \\
\text { menggunakan } \\
\text { ornamen hasil } \\
\text { akulturasi } \\
\text { walaupun } \\
\text { ornamen asli } \\
\text { masih terdapat di } \\
\text { beberapa bagian. }\end{array}$ \\
\hline
\end{tabular}




\begin{tabular}{|l|l|l|}
\hline & $\begin{array}{l}\text { rumah tinggal } \\
\text { yang } \\
\text { menggunakan } \\
\text { ornamen hasil } \\
\text { akulturasi } \\
\text { tetapi dalam } \\
\text { bentuk yang } \\
\text { sederhana/sim } \\
\text { pel }\end{array}$ & \\
\hline $\begin{array}{l}\text { Ornamen } \\
\text { kolom }\end{array}$ & $\begin{array}{l}\text { Ornamen yang } \\
\text { sering } \\
\text { digunakan } \\
\text { adalah ornamen } \\
\text { flora/organik, } \\
\text { berupa okel }\end{array}$ & $\begin{array}{l}\text { Masih } \\
\text { menggunakan } \\
\text { ornamen asli } \\
\text { berupa motif } \\
\text { organis/daun } \\
\text { sulur yang } \\
\text { terdapat pada } \\
\text { kolom, baik dari } \\
\text { bawah hingga } \\
\text { atas ataupun } \\
\text { hanya sebagian } \\
\text { dari kolom }\end{array}$ \\
& & \\
& &
\end{tabular}

\section{Analisis Ornamen pada Tanean Lanjhang}

Tanean Lanjhang merupakan suatu kompleks permukiman yang dihuni oleh sekelompok orang Madura yang masih dalam satu keturunan (genetik). Dalam pemukiman tersebut terdapat beberapa bangunan penusun utama, diantaranya adalah kobhung (langgar), roma tongghuh (rumah induk), tanean (halaman), dapor (dapur), kandhang (kandang), dan rumah untuk anak. Masa bangunan utama tersebut dihubungkan denga ruang publik berupa lapangan. Pada penataan kompleks permukiman tradisional ruang publik merupakan bagian integral dari upaya masyarakat Jawa mencari keselamatan hidup, khususnya dalam membangun relasi dan menjaga keselarasan dengan lingkungan masyarakat (Sumardiyanto et al., 2016).

Pola Tanean lanjhang tidak selamanya mengikuti pola permanen dan kaku. Akan tetapi, ada beberapa pola yang selalu ada dan menjadi ciri utama (Sattar, 2017). Ciri utama yang

dimaksud terdiri dari tiga hal, yaitu:

a. adanya rumah tongghuh yang dibangun di ujung paling barat pada deretan utara dan menghadap ke selatan

b. rumah tongghuh maupun rumah-rumah lain yang dibangun berikutnya tetap menjadi wilayah privat bagi perempuan

c. selalu ada kobhungyang dibangun di ujung barat tanian lanjang dan tetap dibangun dengan desain terbuka dan menghadap ke timur.

Awal mulanya rumah pada pemukiman ini menggunakan gejug/kayu sebagai material utama, tetapi seiring bertambahnya tahun telah terdapat beberapa pemukiman yang menggunakan batu bata pada bagian dindingnya.

Konsep ruang pada rumah induk dan rumah anak adalah konsep ruang tertutup sehingga pada rumah yang bermaterialkan gejug/kayu banyak menggunakan ventilasi udara menggunakan ornamen dengan motif organik/flora. Hal tersebut dikarenakan motif flora tersebut dipasang menumpuk sehingga terlihat tidak ada celah untuk bisa mengintip aktivitas yang dilakukan didalamnya walaupun sebenarnya terdapat celah-celah tak terlihat jelas sebagai ruang sirkulasi udara. Sedangkan pada rumah yang bermaterialkan batu bata telah sedikit mengalami perubahan dengan konsep awal karena sudah terdapat beberapa rumah yang menggunakan jendela sebagai ventilasi utama sehingga ornamen yang terdapat pada rumah ini tidaklah sebanyak yang ada pada rumah bermaterial gejug/kayu, hanya pada ventilasi diatas pintu, kusen jedela, dan sedikit di bagian pintu. Disamping perbedaan yang signifikan itu, motif ornamen pada pintu dan dinding memiliki keseragaman dengan motif pada ventilasi udara, baik itu pada rumah batu bata ataupun rumah gejug/kayu.

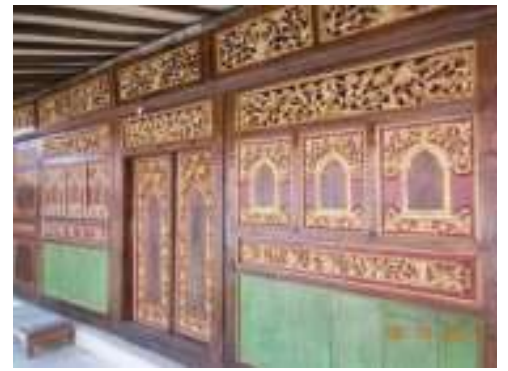

Gambar 10: rumah material gejug/kayu Sumber: detik Travel
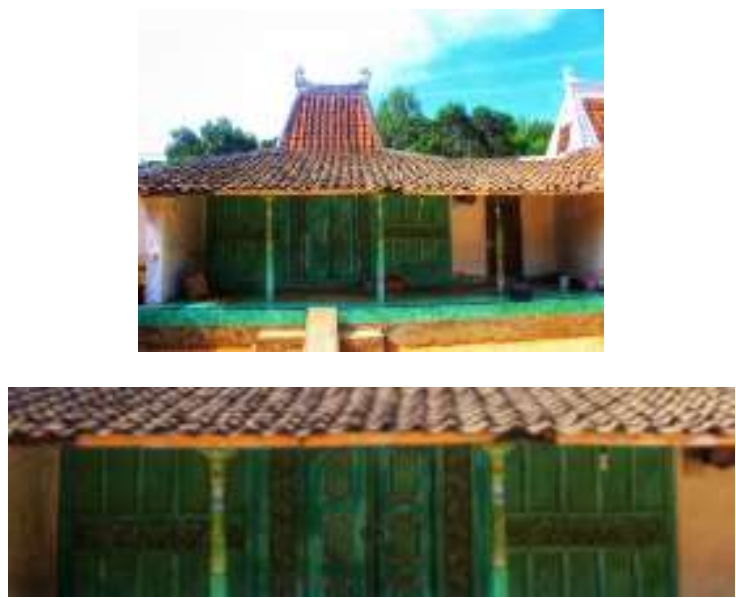

Gambar 11: Rumah material utama batu bata Sumber:blogspot 
Kobhung (Langgar) bagi masyarakat Madura memiliki peranan yang penting, tidak hanya didefi nisikansebagai ruang ibadah, namun langgar menjadiidentitas Tanean Lanjang, hal ini tercermindari pola aktivitas penghuni, dan bagaimanacara penghuni memperlakukan langar (Heng \& Kusuma, 2013).

Pada bagian kobhung (langgar) mulanya menggunakan tabing (anyaman bambu) sebagai dindingnya sehingga tidak terdapat ornamen. Seiring berubahnya waktu hingga dindingnya telah menggunakan batu bata, kobhung sangat jarang terdapat ornament (Nailufar, 2015). Yang ada hanalah berupa relief sederhana berupa motif okel yang sangat sederhana (hanya berupa tangkai utama/tidak ada daun)

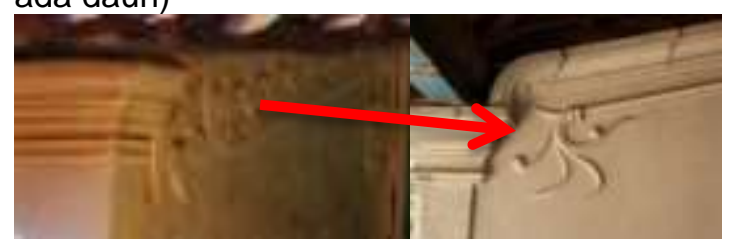

Gambar 12: relief pada dinding langgar Sumber Nailufar, 2015

Pada bagian kandhang dan dapor tidak terdapat ornamen atau relief karena kedua tempat tersebut lebih diutamakan segi fungsinya yakni kandhang sebagai tempat hewan peliharaan dan dapor sebagai tempat memasak.

Secara ringkas disajikan dalam tabel berikut:

Tabel 2. Analisis Perbandingan Ornamen dan

Relief pada Bagian Tanean Lanjhang

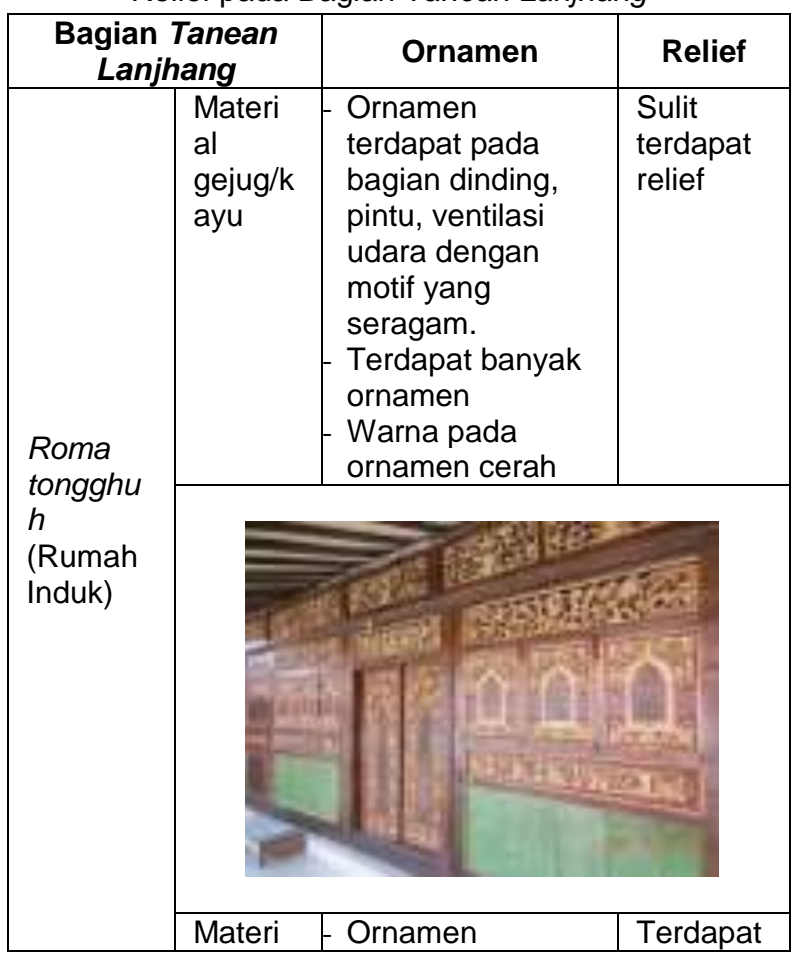

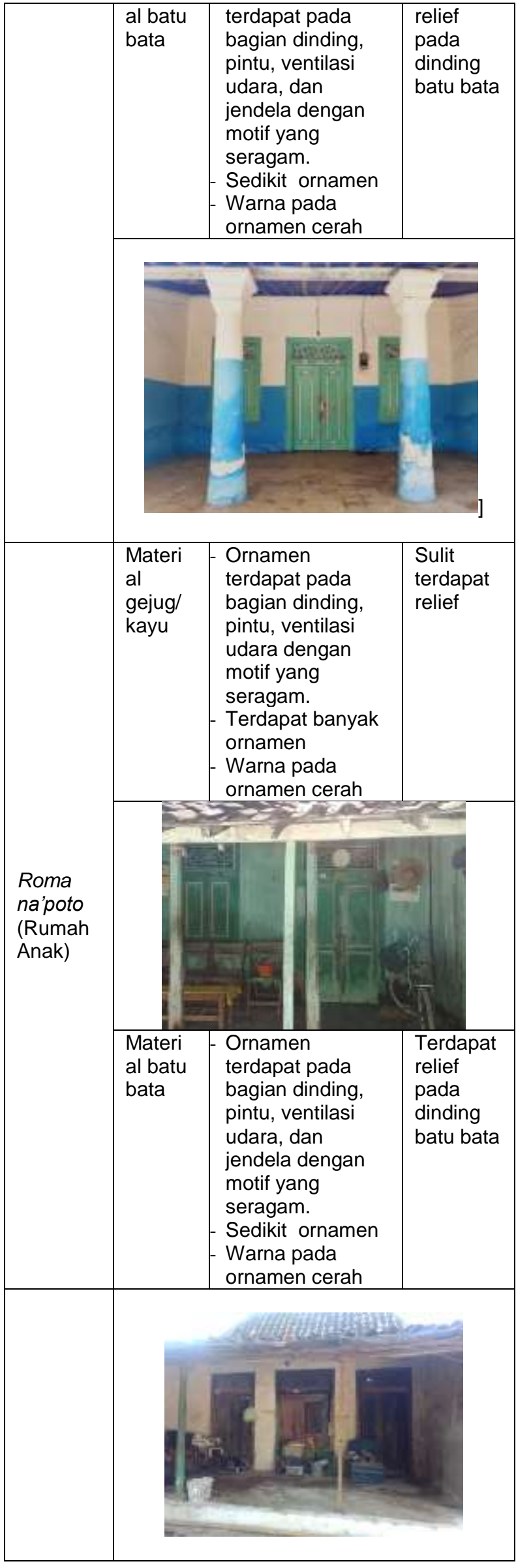




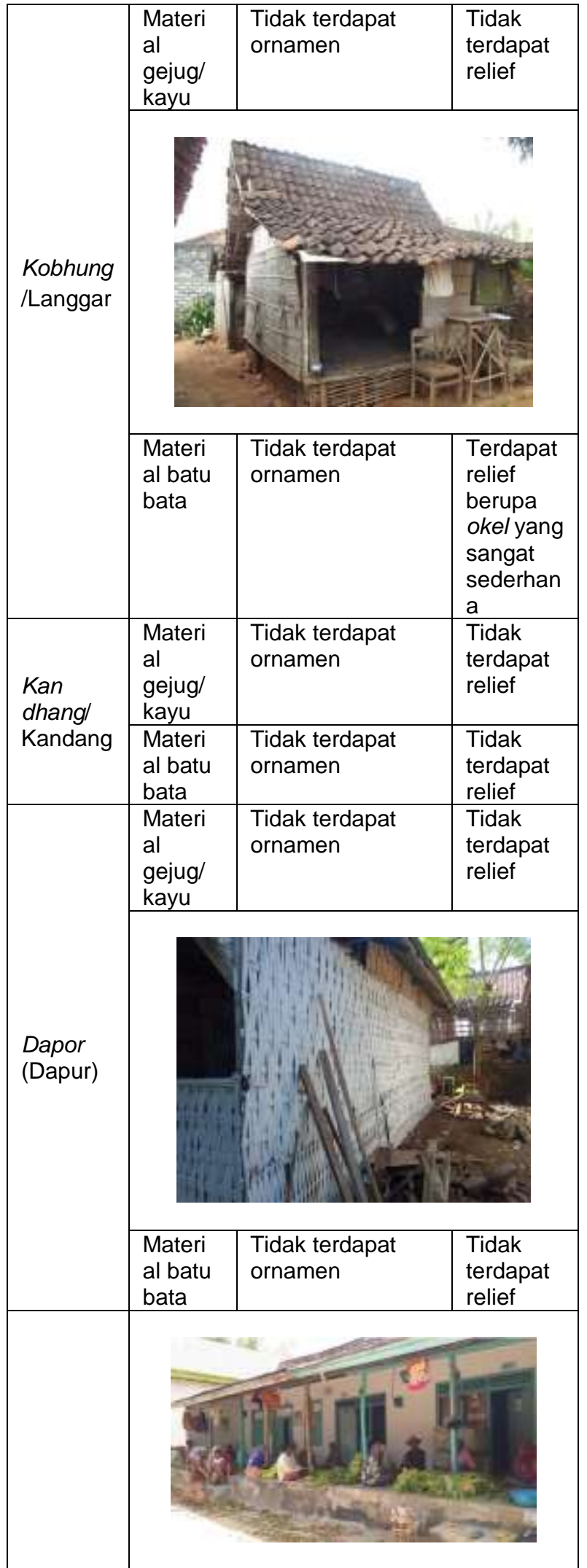

\section{KESIMPULAN}

Berdasarkan hasil analisis yang telah dilakukan, dapat ditarik kesimpulan:
1) beberapa motif yang digunakan pada rumah tradisional Madura antara lain motif flora dengan warna hijau, kuning dan merah yang menyimbolkan kekuatan dan kejujuran. Motif fauna antara lain motif ekor ular yang bermakna mengingat kematian, motif naga bermakna keperkasaan, Motif burung phoenix bermakna kebaktian dan kejujuran hati. Motif yang lain selain flora dan fauna adalah motif swastika yang disebut sebagai motif geometris memiliki bentuk garis yang tegas dan cenderung berulang.

2) Pada motif flora-swastika merupakan akulturasi kebudayaan dari Cina, Jawa hindu, dan Madura. Motif fauna didominasi dengan hasil akulturasi budaya antara Madura dengan Cina. Sedangkan motif flora-fauna merupakan motif hasil akulturasi Madura dan Cina.

3) Untuk area penempatan ornamen bagian atap banyak digunakan ornamen dengan motif ekor ular atau naga, bagian dinding, pintu, kolom banyak menggunakan motif flora.

4) Sedangkan penempatan ormanen pada komplek hunian Tanean Lanjhang adalah roma tongghuh (rumah induk) dan Roma na'poto (Rumah Anak). Pada kobhung (langgar), tanean (halaman), dapor (dapur), kandhang (kandang) tidak terdapat ornamen karena tempat tersebut lebih diutamakan segi fungsinya.

\section{DAFTAR PUSTAKA}

Asmarani, I. K. (2016). Tipologi Elemen Arsitektur Rumah Bangsal Di Desa Larangan Luar Pamekasan Madura. Tesa Arsitektur, 14(1), 10. https://doi.org/10.24167/tes.v14i1.514

Faried, M. (2015). Budaya Madura. Makalah mata kuliah wawasan budaya nusantara. Surakarta.

Gustami, S. (1980). Nukilan Seni Ornamen Indonesia. ASRI.

Heng, J., \& Kusuma, A. B. (2013). Konsepsi Langgar Sebagai Ruang Sakral Pada Tanean Lanjang. Jurnal Arsitektur KOMPOSISI, $\quad 10(4), \quad 217$. https://doi.org/10.24002/jars.v10i4.1167

Nailufar, M. I. (2015). Akulturasi Pada Rumah Tinggal Di Permukiman Sekitar Keraton Sumenep, Madura. Institut Technology Sepuluh Nopember.

Sattar, A. (2017). TANIAN LANJANG Pola Tata Ruang dan Kekerabatan Masyarakat Madura. Sabda: Jurnal Kajian Kebudayaan, 10(2). https://doi.org/10.14710/sabda.v10i2.132 
86

Sumardiyanto, S. ... Salura, P. (2016). Makna Ruang Publik Pada Rumah Tradisional Masyarakat Jawa Kasus Studi: Desa Jagalan Kotagede Yogyakarta. NALARs, 15(1),

https://doi.org/10.24853/nalars.15.1.1-12

Sunaryo, A. (2009). Ornamen Nusantara (Kajian Khusus Tentang Ornamen Indonesia). Semarang: Dahara Prize.

Sutopo, H. (2002). Metodologi Penelitian Kualitatif. Surakarta: UNS Pers.

Wiryoprawiro, Z. (1986). Arsitektur Tradisional Madura Sumenep dengan Pendekatan Historis dan Deskriptif. Surabaya: Laboratorium Arsitektur Tradisional FTSP-ITS. 